\title{
Conservation Farming Through Efficient Use of Resources to Sustain Livelihood of Dry Land Farmers of North-Western Himalayas
}

\section{Neerja Sharma* and Vinod Gupta}

K.V.K. Samba, SKUAST-Jammu, India

*Corresponding Author: Neerja Sharma, K.V.K. Samba, SKUAST-Jammu, India. DOI: 10.31080/ASAG.2020.04.0795
Received: January 30, 2020

Published: February 08, 2020

(C) All rights are reserved by Neerja Sharma and Vinod Gupta.
India is leading vegetable producing country and ranks $2 \mathrm{nd}$ in the world after china in vegetable production. Presently it occupies 6.76 million hectares area with the annual production of 101.43 million tones (Rai and Pandey 2007). The country is blessed with the unique gift of nature of diverse climate and distinct seasons, make it possible to grow an array of vegetables exceeding more than 100 types. Incessant growth of urbanization, ceaseless fragmentation of land holdings and depleting natural resources are the major challenges before expansion of any agricultural commodity either cereals or vegetables. Hence our attention should be focused on vertical expansion strengthened with the boon of technology instead of horizontal expansion just by increasing the crop area.

To ensure the nutrition security of increasing population of the country, it is estimated that by 2020 the country's vegetable demand would be around 135 million tones. To achieve this target, it is important to integrate the various technologies right from production to post harvest.

\section{What is sustainable agriculture?}

Whether you're a beginning farmer, or an experienced agricultural producer interested in transitioning to more sustainable practices, you may want to start by learning more about the principles of sustainable agriculture and some of the "systems" approaches associated with it.

\section{What is sustainable vegetable production}

For the purpose of an introduction, sustainable agriculture can be characterized as follows:

- Sustainable agriculture is a goal rather than a specific set of farming practices. Progress or movement toward the goal may be viewed as a continuum.

- A sustainable farming system strives to be productive and profitable, while at the same time preserving environmental quality and making efficient use of nonrenewable resources.

- Sustainable agriculture is concerned about the well-being of rural communities and the quality of life for families and farm workers.

- Though biological practices and products are favored over chemical inputs, pesticides and fertilizers may be used within an IPM framework.
One of the quickest ways to grasp production practices associated with sustainable vegetable production is to examine the guidelines and standards for integrated farming systems, such as:

- Integrated Pest Management

- Integrated Crop Management and diversification of vegetables

- Organic vegetable production

- Integrated Plant nutrient system

- Post harvest management.

Integrated pest management

- Defined as the harmonious use of multiple tactics to control pests to a tolerable level

- Widely used to minimize loss to fruit, vegetables, field crops, stored products and forestry

- Goal is to limit damage and minimize economic losses in an environmentally acceptable manner

- It is recognized that no single approach can offer a universal solution, thus the need for Integrated Pest Management (IPM)

- Knowledge and understanding the life history and mating habits of the pest is essential.

Risk with chemical pesticides -Agricultural and consumer front

- Indiscriminate use let to the Three sad R's : Resistance, Resurgence and Residues.

- Elimination of Natural enemies of pests

- Upsetting the ecological balance

- Environmental degradation/Pollution

- $\quad$ Beyond the Economic: Farmer, Practices and Identities

- Enters food chain and lead to Bio-Accumulation and BioMagnification.

Specific methods

- $\quad$ Pest free planting: Assure plants are not infected prior to planting. This minimizes the change for introducing new pests to the area.

- Crop rotation: Plant a different crop every other year to minimize adaptation of the pests.

- Physical barriers: Cover plants with material to block the pests from the plants.

- $\quad$ Natural predators: Introduce natural predators that will feed on the insects 
- $\quad$ Trapping: Attract and trap the pest to physically reduce their population in the affected area.

- Genetically modified plants: They have resistance to the pest thus reducing damage that would be inflicted.

- Natural enemies consisting of predators, parasites and parasitoids causing damage to different stages of insects. Trichogramma spp. For control of fruit borer. Similarly Chrysopeda carnea for control of aphids, jassids and eggs of lepidopterous borers. Apanteles plutellae and Diadegma semiclausum for control of diamond back moth.

- Use of bio-control agents like bacteria, fungi and viruses are used for control of different insects and diseases e.g. Trichoderma virdie, Gliocladium vierns etc.

Integrated crop management and diversification of vegetables Organic farming

Organic farming is an emerging area in vegetable production and there is great demand for organically grown vegetables in export. The organic system plan is through record describing the protocols that the operation will use to achieve and maintain the requirements of IOS (Indian organic System). The use of genetically modified organisms is prohibited. Seed, transplants and other planting material should be produced organically. In India there are about 30000 organic farmers and about 8000 organic farms. The main aim is to establish an eco-balance with the nature. It takes a proactive approach towards the environment as opposed to treating problems after they emerge. The market for organic products is growing steadily in Europe, North and South America, Finland, Canada, U.S., Denmark and Sweden. The global market for organic products by 2010 is expected to be around 35-40 billion U.S. dollors.

\section{What is organic vegetable production}

In a nutshell, organic farming is based on the following approaches and production inputs:

- $\quad$ Strict avoidance of synthetic fertilizers and synthetic pesticides

- $\quad$ Crop rotations, crop residues, mulches

- Animal manures and composts

- $\quad$ Cover crops and green manures

- Organic fertilizers and soil amendments

- Bio-stimulants, humates, and seaweeds

- Compost teas and herbal teas

- $\quad$ Marine, animal, and plant by-products

- Bio-rational, microbial, and botanical pesticides, and other natural pest control products.

\section{Diversification of vegetables}

- $\quad$ Promotion of diversification among vegetables especially under utilized and exotic vegetables for export markets

- $\quad$ Crops like sweet corn, baby corn, leek, bunching onion, brocolli, brussels sprouts, Chinese cabbage, faba bean, parsley, parsnip, lima bean, drumstick etc. should be given importance.

\section{Integrated plant nutrient system}

Integrated plant nutrient system involves balanced use of chemical fertilizers, organic manures and bio-fertilizers increases yield, improves quality of vegetables, enhances soil fertility and makes the soil ecosystem sustainable.

\section{Post harvest management}

- To generate appropriate technologies for post harvest management, government intervention through policy decisions are needed which may include input subsidies for establishment of cool chain, processing into value added products, pricing policies, import export tariffs and facilities for marketing.

- $\quad$ Establishment of processing units in production centers based on cluster village concept should be promoted to process vegetables for export.

\section{Assets from publication with us}

- Prompt Acknowledgement after receiving the article

- Thorough Double blinded peer review

- Rapid Publication

- Issue of Publication Certificate

- High visibility of your Published work

Website: www.actascientific.com/

Submit Article: www.actascientific.com/submission.php

Email us: editor@actascientific.com

Contact us: +919182824667 